\title{
Ellipsis
}

2021

\section{Wolf, Witch, Traveler}

Allyson M. Langhoff

University of New Orleans

Follow this and additional works at: https://scholarworks.uno.edu/ellipsis

\section{Recommended Citation}

Langhoff, Allyson M. (2021) "Wolf, Witch, Traveler," Ellipsis: Vol. 46 , Article 20.

DOI: https://doi.org/10.46428/ejail.46.20

Available at: https://scholarworks.uno.edu/ellipsis/vol46/iss1/20

This Fiction is brought to you for free and open access by the Department of English and Foreign Languages at ScholarWorks@UNO. It has been accepted for inclusion in Ellipsis by an authorized editor of ScholarWorks@UNO. For more information, please contact scholarworks@uno.edu. 


\section{Wolf, Witch, Traveler \\ by Allyson Langhoff}

Shirley and Hattie ensured they were completely enshrouded by the troop of trees on the outskirts of the empty field before stopping to take a breath. They'd been in Texas all of two days and already shit was going south. Shirley rolled up the sleeves of her hoodie, a poor choice considering the blistering southern temperatures, but she never felt comfortable without it. She could tell Hattie was sweltering as well, as her normally crisp shirt was unbuttoned, and her curled blonde hair stuck to her forehead. Sweat dripped down Hattie's neck, and Shirley couldn't help but blush as it ran down the hickey Shirley left on her skin the night before. She coughed to refocus herself and adjusted her glasses. They had bigger problems.

Shirley stared at the dilapidated barn standing two-hundred feet away from their position and lifted her fingers to the button on the com-device in her ear.

"Barn on the edge of the field, just like you said," Shirley said into the microphone.

"Perfect," Foot's voice crackled through the earpiece. "Jen's tracker hasn't moved for the past few hours, so she should be somewhere in there. Unless they've cut off her arm, of course."

"No, she's in there.” Shirley could recognize her best friend's aura anywhere.

Shirley had bolted out of her sleeping bag that morning after Jennifer's aura in the camp. She had scrambled out from her and Hattie's tent to see Jennifer's tent standing on the other side of the firepit with the flap drawn down, empty. Jennifer would usually take strolls in the early morning to catch a last glimpse of the moon before dawn took over, so Shirley tried to settle her thumping heart and dove into the lush forest, straining her mind to sense any trace of her friend. Shirley's initial worry grew to absolute terror when she spotted a scrap of Jennifer's shirt amidst a cluster of dilapidated trees covered in claw marks.

Shirley rarely had to sense people across long distances like this. Luckily, Foot's invasive technology served to fill in the gaps where Shirley's magic could not. In this case, it was the trackers the conspiracy nut had implanted in each of their arms.

"These hinky little things sounded like a bad idea at the start," said Hattie, poking at the lump on her forearm. "But even I'll admit they're good in a pinch."

"Just wish you'd asked before installing them, Foot," Shirley said deadpanned, staring at the bump on her skin.

"Next time one of us is kidnapped, you can oversee reconnaissance then," Foot's voice quipped. "Let's do this clean and quick, ladies."

"Roger that," Hattie said into her com-device and looked out toward the barn. "You think any jobbies in there will be packing heat?"

"It's Texas," said Shirley, wiping sweat from her brow. "What do you think?" 
"Glad to see some things don't change," Hattie said, grinning wide and patting the weapons on her belt: revolver on one side, rapier on the other. "Good thing I'm a quick draw."

The two women rushed forward, trying to cross the open field as quickly as possible. The closer they got to the barn, the rougher it looked. The roof had caved in on itself, who knows how many years ago, and the wood was rotted underneath the shredded white paint. If there had once been a door, it was long gone, leaving the barn to the mercy of the elements.

The barn was large, and light streamed down from the rafters to reflect on the scattered bales of hay, rusted farm equipment, and one broken-down tractor. Everything was covered in a fine layer of dirt.

"Creepy little dive isn't it?" said Hattie, drawing the sword from her belt and holding it ready. Shirley admitted it looked more serial-killery than a barn normally should and pushed her hoodie up to grab the pistol tucked into her jeans.

"Nothing super out of place though," said Shirley. "What are we missing?"

"Look a little closer, kitten," said Hattie, who was staring at the dirt floor. On a second glance, Shirley saw a trail of light boot prints that led toward a bale of rather withered hay. Not one to let her guard down, Hattie kept her sword aloft and kicked the hay out of place, revealing a large door implanted in the ground.

"Holy shit!"

"Yup," Hattie said, smirking. "Classic bootlegger trick. I've had to use a few of these myself in my travels."

Shirley bit back a remark involving the perks of having a time-traveling girlfriend,as Hattie gripped the wrought-iron handle of the trapdoor and pulled up. The door lifted without any protest, and Hattie swung it completely open, revealing a rickety wooden ladder that reached into a dark room under the barn.

Hattie extended a hand in Shirley's direction and said, "After you, m'lady."

"I should NEVER have introduced you to the internet," Shirley replied, taking her hand and crouching down to descend the ladder.

She made it down the first few steps fine, but when she looked down into the pitch-black room, she froze. Her grip on Hattie's hand tightened, and she couldn't look away from the void of black that threatened to draw her in. Shirley's mind flashed to memories of being neck-deep in water surrounded by pitch-dark cave, unknown creatures slithering beneath her feet. That dark place was where, for the first time, Shirley encountered anything out of the ordinary, the occult, the things kept secret from this world. Shirley remembered it each time the lights went out. She felt Hattie's lips press against her knuckles, and Shirley snapped back to the present.

"Your best friend is the scariest thing down there," Hattie reassured her. "You can handle anything else. I'll keep watch out here." Hattie squeezed her hand one last time and let go. 
Shirley followed the ladder and dropped down to the ground. She quickly shrugged off her backpack to retrieve her flashlight. Soon, a bright beam of light cut the darkness of the basement, and Shirley readjusted herself.

The area under the barn smelled dank, like soil and standing water. The flashlight only extended so far, getting swallowed up by the dusty darkness so Shirley couldn't see the end of the room from this vantage point. The basement most likely ran the length of the barn, hiding whoknows-what in the depths. Shirley shined the flashlight along the closest walls. Maps covered in strange red marks leading from state to state were held up with mismatched thumbtacks. Some displayed local topography with small red X's on them, and red lines of yarn connecting them to various pictures: blurred images of bigfoots, shining balls of light from the sky, a black car with men in suits and sunglasses.

The opposite wall was covered in weapons of all kinds. Gnarly knives hung from hooks alongside about a dozen guns that were, as Shirley suspected, loaded. A barrel full of wooden stakes stood in a corner alongside a few worn crucifixes. A table in the far corner was covered in more maps, a few spare radio parts, and in the center sat a leather bound book. It was deep purple and the metal clasp keeping the book closed was bronze with a skull symbol stamped into it. Shirley tried to get closer to investigate further, but the moment she did, her stomach began to churn as she saw the gray aura swirling through the air around it. Objects rarely emanated magic like this. The danger level of their situation immediately spiked.

Shirley tread lightly as she wandered deeper into the basement, feeling more like a horrormovie protagonist with every step. She could practically hear an audience yelling at her to turn around and get the hell out of there. Weaving between the stacks of forgotten bric-a-brac, Shirley noted how normal it all looked: the old boxes, empty oil canisters, broken down and rusted mechanical bits, a wooden duck decoy any grandfather would have. That was the scariest part about this job - the most terrifying people seeming completely ordinary.

A throaty snarl rang out from the darkness, making Shirley jump and drop the flashlight. As it rolled along the floor, the light illuminated a thick chain-link gate. Shirley snatched up the light and cast the beam along the gate. The interwoven links extended up to the ceiling, essentially creating a huge cage on the far side of the room.

A metal clatter rang out as the creature inside got an eyeful of the light. Her pupils dilated into little points, and she shirked away to hide her face. The creature was humanoid, large and muscled, and covered in light brown, nearly blonde fur. The claws on her hands and feet were torn up and bleeding near the flesh. The creature curled into a tight ball in the corner of the makeshift cell. Shirley's heart nearly stopped; she'd never seen Jennifer look this bad.

"Jen? You still yourself in there?" Shirley asked in a shaky breath.

The beast—-Jennifer — rushed toward the gate and snarled again. Her muzzle pulled back slightly to reveal jagged teeth. She growled as Shirley got closer, hazel eyes following her every move as if looking for some sign of a trick. A glint of red dripped down the creature's arm, spilling from the large, bleeding hole in the werewolf's shoulder. 

do?"

"Crap," Shirley said, winding her fingers around the links of the gate. "Jen, what did they

Jennifer's eyes glared back at her through the cage, and a look of recognition shined across them. She lifted a claw to point at the weeping wound.

"Silver bullet?" asked Shirley.

Jennifer growled as confirmation.

"Assholes," said Shirley. "That's a cheap move. Why haven't you changed back then?"

Jennifer pawed at the cage, which barely shook at the contact. Shirley let her fingers trace the intricate shapes of the link, and it took only a moment to recognize the material.

"Silver-infused steel. Fuck."

It made sense when she put the pieces together. The weapons and maps could belong to any wannabe hunter type, but this cage meant whoever set this place up was a specialist — one who knew silver traps drained shapeshifters' energy and kept them from regaining human form, a sick form of torment.

Shirley tucked the flashlight into her belt loop and closed her eyes. She needed to block everything out. The sounds of Jennifer's weakened snarls, the creak of the unstable barn above, and the musk of the closed-off room all faded from her thoughts as she mentally reached for the threads that connected to the unseen veil of magic all around her.

She held out her hands and bright blue sparks flew from her fingertips to encircle the silver chain-link. Shirley could feel the power melded into the structures. The cell was made by newer magic. It was flashy and strong, but it contained flaws that the ancient magic could manipulate. She extended her arms outward, inch by inch, and the sparks broke the gate, link by link, tearing an opening through the silver cage. The sound of twisting metal filled the room, and with one final wrench, the gap opened wide enough for Jennifer's hulking form to get through.

As the blue sparks faded from Shirley's hands, Jennifer lumbered out of the cell and rose to stand on two paws. Shirly gingerly took her arm and led the injured wolf away from the gate. The moment Jennifer was out of range, her muzzle sank inward, her spine straightened, and she shrunk about a foot.

Jennifer's muscular form shifted into one that was much leaner, and the hair covering her body receded into smooth skin, leaving only a matted mane of platinum blonde hair on her head. Jennifer now stood before Shirley in her human form, stark naked and bleeding, clutching at the wound in her shoulder. Jennifer had prettier features than Shirley, as many people back in high school had felt important to point out, but her beauty was currently masked as her face contorted in rage and pain. Her lively, deep brown eyes were red from tiredness, her under eyes swollen, and her usually warm, pink lips were now pale and drawn into a snarl. The wolf was never far behind. 
"I'll...fucking kill them," Jennifer growled through clenched teeth, before collapsing into Shirley's arms.

They held each other for a moment. Shirley rocked back and forth, cradling Jennifer's shaking body, and Jennifer buried her face in Shirley's hoodie to let out a racking sob. Shirley rubbed circles on her back counterclockwise, the way Jennifer liked, and whispered soft You're okays and I've got yous until Jen was calm enough to explain how she'd been taken.

"Woke up when it was still dark," Jennifer croaked, her throat dry. "Heard a wolf howl. Not a regular one; one like me. It was too far away for y'all to hear it, but I could. It sounded so sad, Shirley. I had to go to it." Jennifer clutched her tighter. "I transformed so it wouldn't be scared when I found it, but the hunters found me instead." Jennifer's hollow voice grew harsh. "They had recorded the voice of another werewolf and used it as bait. How effed is that? Got me right where they wanted me. I tried to fight back, but they put some kind of spell on me. When I woke up, I was here and couldn't change back."

"What kind of spell was it?"

"Don’t remember, girl. Feels like I got whacked with a baseball bat."

Shirley nodded and tried to recall any spell side effects from her studies that fit that description as she retrieved Jen's spare set of clothes from her backpack. Shirley turned the flashlight on and tucked it under her chin to keep her hands free. They gingerly stretched Jen's college cheerleading shirt over her head and injured shoulder and pulled up her jean shorts.

Shirley guided Jennifer through the basement maze, only slowing when the ladder came into view. Jennifer eyed the memorabilia on the walls with a mix of skepticism and caution.

“Any of them explain why they took you?" asked Shirley.

"They're fucking crazy, Shirl," Jennifer said, shrugging. "They're in some kind of cult probably. The hunters kept rambling on about how my blood was unclean or some shit."

"Well, they've gotten enough of your blood by now," Shirley said as she pressed on her earpiece to update everyone. "Foot, we've got her. Bring the van around."

"Gotcha," crackled Foot's voice. "Be there in-" She was cut short by three quick bursts of gunfire followed by a drone of white noise.

"Welp. That sounded good," Jennifer said dryly.

More gunshots rang out from the room above them, and a chill went down Shirley's spine. There were shouts from above, and a scuffling sound resonated from the earpiece before, much to Shirley's relief, Hattie's voice cracked through.

"They drove up in some gaudy automobile and surprised me," she said. "Don't know how many there are, but one's got a gat aimed at your exit." As if for emphasis, a half dozen bullets were shot at the opening, a few hitting the ladder and sending sparks flying everywhere. 
Jennifer trudged forward and moved to climb the ladder before Shirley pulled her back.

"No chance," Shirley said. "You're already hurt."

"Hon, it's a flesh wound," said Jennifer, lying through her teeth. The opening in her skin was starting to sizzle.

Shirley winced. All their medical supplies were in Foot's van, but she had no way of knowing if or when the vehicle would arrive.

"I'm a big girl. I can take a few more hits."

A few more, maybe, but who knew what they would encounter up there. Still, there was no denying Jennifer when she got that feral look in her eye.

"I'll cover you," said Shirley. She wouldn't be able to hold a protection spell for very long, not after she spent so much energy destroying the cell, but it would give Jennifer enough time to surprise their guests.

"Just watch," Jennifer said, pulling herself up the steps with shaking arms. "They're gonna look worse than Sebastian Richards did when I caught him cheating." Her body rippled back into her wolf-like state, tearing the fresh clothes away. She stood poised for Shirley's signal.

Shirley had to push past the fear of her thumping heart and the gunfire sounding from upstairs to concentrate on the opening of the trap door. She envisioned a clear, protective shield surrounding it. The veil shifted to do as she commanded, and she felt the barrier snap into place.

"Now!" Shirley yelled. Jennifer surged out of the opening with a growl, and a male voice yelled out in shock.

Shirley scampered up the ladder and had only a few moments to assess the situation up top. A beaten-up pickup truck was parked just beyond the opening in the barn. A flagpole was attached to the tail end, upon which was a limp, purple banner with the same skull icon as the book downstairs.

There were five men, each wearing some variety of leather jackets or flannel shirts. A man in a ball cap , standing in the entrance to the barn, aimed a shotgun in Shirley's direction and fired, only for her barrier to deflect the bullet with ease. It wouldn't hold for too much longer though.

Three of the men surrounded Jennifer and attempted to back her into a corner. One fool, wielding a silver-plated knife, swung his arm to stab at her. She caught his hand in her jaws and sunk her teeth into his flesh. He yelped as she shook him to keep the others away.

Hattie popped up from behind one of the rusted tractors and fired a few shots from her pistol at the man standing in the entrance before finding cover again. She spotted Shirley and called out, "Join the fun, love!" 
Shirley almost laughed, but before she could, the air filled with the crack of another shot, and she winced as something grazed her forearm. She turned to see her barrier fading; the shooter at the entrance had nearly hit his mark. Blood dripped from the wound, but she ignored it as she dashed toward Hattie's hiding place and crouched down next to her.

“Does Jennifer need backup?” Hattie asked as she reloaded her pistol.

"She was doing fine a second ago." Shirley pulled her gun out of its hiding place and turned the safety off. "But she can't hold out much longer."

"Got it," Hattie got to her feet, picked her rapier off the ground with a flourish, and dashed off in Jennifer's direction.

Shirley could feel fatigue setting in already. Using spells one after another usually made her feel as if she'd run five miles. She held the gun aloft as she poked her head out again. Hattie and Jennifer were occupied by a couple of men trying and failing to take Jennifer down emptyhanded. The gunman at the doorway peeked out to aim his gun in their direction, but Shirley lifted her pistol to aim for his head.

Her arm wasn't ready for the recoil, and the sudden change of movement sent the bullet a few inches above the gunman's head, missing him completely. She'd never been the best shot, and now she'd given away her position. Shirley dug down deep to pull at the threads of magic connecting the gunman to the earth and made a tugging motion with her hands. The man was pulled off his feet by an unseen force and hit the wall with a loud thud.

Shirley dashed out from her hiding spot and toward Hattie and Jennifer, who'd managed to knock one of the men out. Jennifer held the last of the ambush, a gaunt bald man, in a headlock as Hattie aimed her rapier at his neck.

"Tell us what you needed her for," said Hattie, nodding to Jennifer. "And we'll consider letting you go.”

Despite being threatened with a blade, the man had a smug look on his face. "You deface the purpose of humanity by aiding this creature," he spat.

"We'll be havin' none of that now," said Hattie, pressing the tip of the blade closer to his throat. "What did you need her for?"

"That creature's kind aren't needed here," he muttered, and Jennifer seemed to squeeze him tighter. "None of them are."

His eyes met Shirley's. He stared at her for a moment, and she could feel the faintest similarity between his aura and the books downstairs. It was a state of hatred and disgust.

"You," he said to her. "You've felt the veil yourself. Felt it tainted by the unclean. Those possessed by unclean spirits must be cleansed." 
She was able to feel the veil. She felt the man's presence in it, as he made small, insignificant tugs toward its power to no effect. He couldn't connect to it, didn't have the gift.

"No," said Shirley scathingly, "you do this because you're weak. And taking down these people makes you feel stronger."

"You know well that it is man and not the wolf who will rule the earth," the man shouted, growing more aggressive. "You who welcome the besmirching of the Earth shall join them in hell!"

"Oh, someone is going to hell all right." Hattie put more pressure on the blade at the man's neck, and Jennifer growled in agreement. Shirley saw something move out of the corner of her eye. The man Shirley thought was unconscious had neared while their attention was diverted. He rushed forward in Hattie's direction, and the light streaming in from the outside glinted on something silver in his hand.

Shirley only had a second to react and barely registered that she'd lifted the gun before firing a shot. It must've been mere inches from Hattie's head because she jerked back in surprise, her would-be attacker dropping the rifle and falling to the dirt. When she caught Shirley's eye, a proud smile spread across her face.

"We will not be silenced!" shouted the man in Jennifer's arms, clearly not happy about the diversion of attention from him. "Even if my life ends, there are others who will continue. We will continue the cause no matter the price. We-"

Hattie silenced him with a slash of her rapier across his neck, and Jennifer dropped his bleeding form with a growl indicating her disgust. He spluttered for a few moments, and Shirley felt his aura drift away like campfire smoke.

When they were sure they were alone again, Hattie descended the ladder and returned with the purple book. Shirley had intended on incinerating the thing, but Jennifer snatched it from Hattie and tore it to shreds within a few seconds. Just as she'd finished, a car horn blared from outside the barn, and all three ran to investigate.

A white van with three bullet holes in the windshield sped through the tall grass toward them, barreling through an upturned water trough and sending splintered wood flying. The van skidded sideways from the impact, and the wheels went into overdrive to regain balance of the vehicle. It screeched to a halt a few yards ahead of them, and the van doors opened from the inside. Foot, ginger and bespectacled, gave them a frustrated look before hopping back into the driver's seat.

"They had guys scouting the woods. Got ambushed," she explained, breathless. "One of 'em must've called the cops; they are right behind me."

Shirley could already hear faint police sirens in the distance, and she clumsily helped Jennifer, who was morphing back into human form, into the front seat for Foot to patch up. 
Shirley was about to leap into the back seat when her arm was yanked from behind as Hattie pulled her into a deep kiss. Shirley gasped but melted into her touch, gripping tight to Hattie's waist. When they broke apart, Hattie's chest heaved, catching her breath.

"Good aim, doll," Hattie said, her voice about an octave lower than usual, that familiar devilish look in her eye. "I could still give you a few pointers though."

"Shut up," Shirley scoffed, pressing her forehead into Hattie's shoulder to hide her flushed face.

The mood did not last, as the van's horn blared again, and Shirley whipped around to see Foot staring at the pair of them, bemused.

"Either get the hell inside," she said, "or bang and get arrested. Your choice."

"We'll finish this later," whispered Hattie with a wink, and both women jumped into their usual seats as Foot floored the gas pedal, speeding the van north toward the main road.

"The usual escape method if you please, Shirley," requested Foot. "You probably got a recharge from Amelia Earhart there."

Hattie made a noise of protest, and Jennifer cackled.

"Not much juice left," Shirley warned, feeling faint. "I can give us ten minutes. Maybe."

"I can lose them in five," said Foot.

Shirley shut her eyes, letting nothing past her senses other than the rumble of the car beneath her.

The officers of the Texas Highway Patrol would never have believed it if they hadn't seen it with their own eyes. Just as their squad cars pulled around the dirt road that led toward the barn, they were baffled to witness a large white van charging directly toward them, only for it to vanish before their eyes. An engine roared as a lone set of tire tracks quickly maneuvered around the cluster of cars and down toward the main road. 